\title{
HEGELIAN DIMENSIONS OF THE SECOND SEX: A FEMINIST CONSIDERATION
}

Simone de Beauvoir's philosophical analysis of alterity in The Second Sex represents an ambitious feminist attempt to target the problem of women's otherness and discover the means by which women can overcome this secondary status. Beauvoir's project, motivated by her desire for women to gain access to the privileges of men-especially, to attain what she deems the ultimate privilege of men within a realm where women are trapped in immanence:

transcendence-falls short of this aim. Further, it exhibits, in Kristevan terms, a "logic of identification" with dominant logical and ontological values ("Women's" 19) insofar as Beauvoir's text, at the same time that it interrogates these values, discloses its indebtedness to masculinist philosophy and its major paradigms. Far from diminishing the tremendous impact The Second Sex has had on feminist scholarship, however, these factors have given an impetus to ongoing debates. Beauvoir's undertaking, thus, remains a relevant and generative project more than fifty years later, as feminist thinkers continue to explore key issues such as the terms of the desired transcendence and the inevitable implicatedness of feminisms' relationship with the writings of traditional, masculinist philosophers.

One crucial component of Beauvoir's engagement with phallogocentric thought which has inspired a virtual wellspring of recent scholarly discussion is her Hegelian project. ${ }^{1}$ While it is true

${ }^{1}$ In an article originally published in French in 1994, Michèle Le Doeuff notes the influence of Hegel on Beauvoir's thought and, in particular, on The Second Sex; Le Doeuff claims that the text is "a prolongation of the reading of Hegel already used as an epigraph to She Came To Stay" ("Simone" 64), which reads: "Chaque conscience poursuit la mort de l'autre," or "Each conscience seeks the death of the other." This claim marks a shift in the tide of Beauvoir scholarship (away from its univocal consideration of Beauvoir's Sartrean dimensions). Recent scholarly investigations into the relationship between Beauvoir's thought and that of Hegel include those by Tina Chanter, Edward Fullbrook and Kate Fullbrook, Eva Lundgren-Gothlin, and Elaine P. Miller-all of which contain vital insights into the relationship between Beauvoir and Hegel, rather than Beauvoir and Sartre. Patricia Jagentowitcz Mills suggests that contemporary feminisms' concern with Hegel, in fact, began when "Beauvoir 
that Beauvoir relies heavily on Sartrean notions of the self, the development of which seems to have been a mutually informed project, ${ }^{2}$ she transposes Sartrean categories onto a Hegelian model of the selfalienated spirit. Beauvoir's engagement with Hegelian philosophy, thus, yields a notion of consciousness as dualistic and leads to the assertion that the action of consciousness itself constitutes a set of oppositional, conflictual social relations because the self, or the subject, defines himself in relation to others as objects. This self-other schematic, central to The Second Sex, proves to have limiting consequences for the concept of otherness as a liberating force. Further, through her use of key moments from Hegel's mastertext, The Phenomenology of Spirit, namely, the meeting of human and divine law in the ethical world and the infamous and oft-misused master-slave dialectic, Beauvoir illustrates how women's alterity, as she conceives it, frustrates women's project of transcendence. ${ }^{3}$

This essay will illustrate how Beauvoir's attempt, however "devious,", to cultivate the potential within male philosophical systems

creatively appropriated parts of [Hegel's] philosophy for the development of her analysis of woman as Other in The Second Sex" (2). ${ }^{2}$ Scholars who have documented the mutual influence of Beauvoir and Sartre on each other's intellectual work include, among others: Debra Bergoffen, Fullbrook and Fullbrook, Sara Heinämaa, Sonia Kruks, Michèle Le Doeuff (Hipparchia's), Eva Lundgren-Gothlin, Margaret Simons ("Beauvoir's Early"; "Beauvoir's Philosophical"), and Karen Vintges. Fullbrook and Fullbrook as well as Simons have been instrumental in not only examining the reciprocal relationship between these two thinkers but also highlighting Beauvoir's influence on Sartre. Of particular significance is Beauvoir's origination of the theme, "the opposition of self and other" (Simons, "Beauvoir's Early” 186; Benjamin xi).

${ }^{3}$ Elaine P. Miller suggests that nonconflictual models of human intersubjectivity and human existence emerge from reading The Second Sex in conjunction with The Ethics of Ambiguity; however, I intend to examine the ways in which Beauvoir's Hegelian project functions productively in The Second Sex itself.

${ }^{4}$ Linda M. G. Zerilli asserts, as do I, that Beauvoir "speaks deviously" in the words of dominant discourse, revealing absurdity and dissonance, as well as corruption, in masculinist cultural assumptions and philosophical conclusions about women. Zerilli states, “. . . Beauvoir does not hand women over to the fatalism of teleological narratives [ . . 
in her design for a liberating feminist philosophy, particularly her utilization of a dualistic, oppositional conception of consciousness, which she derives from her reading of Hegel, ultimately thwarts the theory of alterity she develops in The Second Sex, if her aim is indeed women's transcendence. However, an analysis of Beauvoir's projectespecially her consideration of certain pivotal philosophical moments from the Phenomenology —reveals much more than a limited, historically conditioned perspective, including Beauvoir's problematic commitment to the male philosophies that influenced her own intellectual identity: Through her engagement with key Hegelian paradigms and narratives, Beauvoir succeeds in targeting phallogocentric thought at its core, setting ideas in motion, and ultimately creating conceptual spaces for the projects of future feminists. Her impressive study lays the groundwork that has not only informed future feminist strategies but itself transgresses generational boundaries of feminist thought. ${ }^{5}$ This is a subject which demands further scholarly attention as well as a deep appreciation for the legacy she has inspired. But before embarking on this task, a brief consideration of what is involved in the engagement of masterdiscourses will perhaps help to contextualize Beauvoir's undertaking.

\section{Introduction: Engaging Masterdiscourses/Engaging Hegel}

The exclusion of women and "minorities" from history and the masterdiscourses of philosophical tradition poses a challenge to feminist theory and philosophy: it does not seem possible to employ the tools of patriarchy for feminist ends. Further, it may seem reasonable, or even necessary, for feminisms to reject a philosophical past built upon this fact of exclusion and invested in the perpetuation of patriarchy, as well as other systems of domination. However, the

.] but, rather, writes into the dominant sacred and secular narratives a struggle that decisively alters their meanings" (118-19). The selfserving misrepresentations inherent in masculinist discourse are challenged by Beauvoir's (at times mimetic) discursive strategy of engagement.

${ }^{5}$ Several feminist readings of Beauvoir have demonstrated a commitment to liberating her from the constraining category of the "first generation" and its singular concern for the "politics of equality," such as Emily Zakin's reading of Beauvoir which establishes that "there is good reason to recognize Beauvoir as on the vanguard of the third generation" (109). 
possibility of dispensing with these texts and paradigms seems implausible. These ideas and constructs are intertwined with our thoughts, language, and perceptions, and they are embedded in our social ideals, political structures, and the fabric of our everyday existence. There is little likelihood of completely surpassing our philosophical inheritance. Yet, even if this were feasible, we must question the efficacy of such an enterprise.

While a complete rejection of our intellectual forebears is difficult to imagine, we may consider an antagonistic relationship, which might consist of an interrogation of philosophical texts, insofar as they have excluded and devalued women and other marginalized groups, and a denunciation of such texts for their phallocratic and hegemonic content. However, while critique is, indeed, a crucial component of any brand of cultural or sociopolitical theory, this activity is limited in its scope and effects, and not simply because it is intrinsically implicated by these texts. By contrast, the enactment of engagement as a strategy takes into account the inescapably impure relationship of feminisms with mastertexts, and it also acknowledges the possibility that there are valuable resources within the problematic assortment of texts and ideas comprising philosophical tradition, a fact which did not escape the attention of Simone de Beauvoir and continues to occupy the projects of committed feminisms.

Contemporary feminists have demonstrated that a simultaneous invocation of philosophical tradition and refusal of discursive authority, a self-conscious and self-critical maneuver, makes it possible to invoke voices from the phallocentric philosophical past in order to locate tools for radical transformation. In a complex exchange with patriarchal philosophical tradition, the writings of contemporary figures, such as Luce Irigaray and Julia Kristeva, respond to the masterdiscourses of this tradition as well as build upon moments therein that exceed themselves. Their reappraisals and consequent appropriations prove that whether a text is feminist or patriarchal depends on contexts, users, uses, and effects and that, due to the many possible readings and applications of mastertexts, it is possible that traditional texts may be established as provisional, momentary feminist texts or resources. This is, naturally, a source of feminist controversy. However, a decidedly irreverent posture and an insistence on remaining mobile distinguish these projects from mere appropriations. This type of engagement cultivates a necessarily "impure," reflective, and mediated relation to philosophical origins. 
Feminisms' engagement with phallogocentric thought may be traced historically by its repeated return to Hegel. The rationale behind this consistent engagement may be the powerful influence Hegel has had on intellectual history, or perhaps the potential Hegel's work may provide for those who read against the grain of his thought. I do not wish to assert that Beauvoir consistently maintains a position of conscious defiance to the historical and philosophical perspectives of her intellectual forebears, including Hegel. Nor will I claim that she simply appropriates Hegelian philosophy. Rather, by exploring the intersection of a central text in feminist philosophy, The Second Sex, and a dominant narrative within the masterdiscourses of philosophical tradition, Hegel's dialectic in the Phenomenology, and by examining the limitations and excesses that result, the philosophical complexities surrounding the strategy of engagement can be partially illuminated, and we may begin to ascertain how the resources of engagement may be turned against phallocentric thought and even used to reconfigure theorizing itself. The dynamic economies of possibility that best counter and displace the effects of patriarchy may, in fact, emerge from this mode of interaction which privileges negotiation, reciprocity, and mediation. Therefore, the relationship between feminist texts and "patriarchal texts" (symbolic texts/those of the dominant order, or hegemony) may itself symbolize the efforts of feminisms to transcend hierarchical power relationships in both theory and practice. What is privileged here is a form of continuous struggle, or negotiation between forces, which, if enacted on a grand world-historical level, holds promise for an array of radical political enterprises.

\section{Beauvoir's Hegelian Dialectic}

Thus, Beauvoir's use of Hegel in The Second Sex establishes her project as a historical precursor to the strategies of contemporary feminists who consistently revisit Hegel's Phenomenology as a site of contention. ${ }^{6}$ In her text, Beauvoir chronicles the passage of feminist

\footnotetext{
${ }^{6}$ Notable examples are: Kristeva's implementation of Hegelian negativity in her text, Revolution in Poetic Language, where negativity becomes a disruptive force within the symbolic rather than a force which drives dialectical movement towards ideational closure or unity, and Irigaray's treatment of Hegel's reading of Antigone in her essay, "The Eternal Irony of the Community," where she exposes Hegel's ethical order as a rationale for masculine knowledges. Irigaray continues to engage with the phallic economy and masculinist concepts of the Hegelian dialectic in her more recent work on the universal as
} 
consciousness through a project of negation and transformation, a dialectical movement of consciousness towards the aim of transcendence similar to the movement of Spirit in Hegel's Phenomenology. In her appropriation of the Hegelian dialectic, Beauvoir presents women's consciousness not as a simple reflection on external material conditions or an acute perception of a state of affairs intolerable to women, but as a dialectical relationship between consciousness and concrete circumstances wherein conditions are revealed as contradictions. This leads to an apprehension of possibility, a crucial advance towards gaining power. In itself, this process of feminist consciousness is insufficient for the kind of transformation necessary for women's transcendence, but it leads to the search for the means of overcoming conditions-existing both in the world and within women - which support oppressive structures and to the development of direct forms of struggle against those structures.

Beauvoir may have implemented Hegel's philosophical apparatus because she found that his concept of historical change, the continuous struggle toward a higher principle of freedom, illuminated the nature of freedom. Or perhaps, like Marx, she believed that the revolutionary aspects of this ideological justification of patriarchy and philosophical hegemony could be turned against the systems it perpetuates. In any case, Beauvoir does not overtly illustrate how the Hegelian system contains both philosophical potential and the very principles against which women must struggle, as she does with Freud, for example, in her section on Psychoanalysis. ${ }^{7}$ And, unlike her

mediation and the universal as two in Sexes and Genealogies, je, tu, nous, and I Love ToYou.

${ }^{7}$ In Chapter II, "The Psychoanalytic Point of View," Beauvoir acknowledges both the valuable insights and the inherent flaws in Freudian psychoanalytic theory. She derives her "essential objections" to the psychoanalytic point of view "from the fact that Freud based it upon a masculine model" (41). Thus, Beauvoir critiques the masculine biases in Freudian psychoanalysis and ultimately identifies a rationale for male domination therein. Yet she incorporates her extensive and sophisticated knowledge of psychoanalysis throughout her text. One example is her reading of embodied subjectivity in Part IV, "The Formative Years," where her apprehension of the phallus as a symbolic rather than a genital reality factors into her analysis of how the girl does not experience her difference as a lack, but "finds herself situated in the world differently from the boy" (Beauvoir 272). 
feminist successors, she does not explicitly interrogate the tools of the Phenomenology. Yet her own moments of excess-beyond the bounds of her "first wave" status and standard readings of her work-provide vital material for later projects, the full consequences of which have yet to be explored.

\section{Beauvoir's Concept of Otherness}

In answer to the question, "what is a woman?" Simone de Beauvoir confrontationally recites the Latin phrase for "woman is a womb," thus beginning her discussion of the category of the Other and her exposition of her theory of alterity in the introduction to The Second $\operatorname{Sex}(\mathrm{xxv}){ }^{8}$ This identification of woman's status as a sexual and reproductive being proves insufficient, however, for the location of femininity, which Beauvoir deems the basic defining attribute of woman. Femininity, according to Beauvoir, is not a biological fact, nor is it a metaphysical essence, although she identifies biology as a crucial factor of woman's status within the spheres of philosophical and cultural mythology and locates therein a variety of attempts to reify woman into a Platonic essence on these grounds. Beauvoir cites Aristotle's claim, "The female is a female by virtue of a certain lack of qualities ... we should regard the female nature as afflicted with a

\footnotetext{
${ }^{8}$ All Beauvoir citations will be references to the Parshley translation of The Second Sex, a much-contested translation, to be sure, but the most widely implemented English version of Beauvoir's text to date, resulting in its extensive proliferation within U.S. academic circles. Luise Von Flotow's article, "Translation Effects: How Beauvoir Talks Sex in English," points to the voluminous critiques of the Parshley translation of The Second Sex, as well as other French to English translations of Beauvoir's work, highlighting the misogyny that is inserted and the philosophical overtones that are erased by translation effects. While selective abridgement and other key translation issues do distort the character of this text, and there are many who vigorously attempt to get at the "real" text or the "source text perspective," as Von Flotow puts it, the fact remains that the Parshley text is prominently used, even in the graduate classroom, and comes to represent Beauvoir's views to a large-scale audience. Therefore, despite the ways in which the text is altered to reflect both the translator's own sexism and the publisher's pandering to the perceived tastes of a mid-twentieth century audience, the study of this text is worthwhile, including its translation effects, which have themselves provided a fruitful source of academic criticism and philosophical critique.
} 
natural defectiveness," as well as St. Thomas' pronouncement of woman as an "imperfect man," and an "incidental" being, the symbolic representation of which resides, she explains, "in Genesis where Eve is depicted as made from ... 'a supernumerary bone' of Adam” (xxviii). Thus, she begins her elucidation of the "secondary, derivative ontological status" of the Other (Simons, "Beauvoir and Sartre" 172).

That woman is essentially a sexed being within these spheres factors profoundly into Beauvoir's provisional construction of the categories of Self and Other. She asserts, "And she is simply what man decrees; thus she is called 'the sex,' by which is meant that she appears essentially to the male as a sexual being. For him she is sex-absolute sex, no less. She is defined and differentiated with reference to man and not he with reference to her; she is the incidental, the inessential as opposed to the essential. He is the Subject, he is the Absolute-she is the Other" (Beauvoir xxviii). This binary does not, however, trap woman, "the eternal feminine," in the subordinate component of Cartesian dualism, but it does differentiate her according to her sexed identity. Beauvoir and later French feminists, such as Luce Irigaray, in fact, maintain differentiation as a key facet to reciprocity between subjects.

There is no symmetry between the sexes in the self-other dichotomy, but there is an opposition, nonetheless; and it is an opposition without reciprocity. Beauvoir states, "In actuality the relation of the two sexes is not quite like that of two electrical poles, for man represents both the positive and the neutral, as is indicated by the common use of man to designate human beings in general; whereas woman represents only the negative, defined by limiting criteria, without reciprocity" (xxvii). Furthermore, she explains, "It amounts to this: just as for the ancients there was an absolute vertical with reference to which the oblique was defined, so there is an absolute human type, the masculine. Woman has ovaries, a uterus; these peculiarities imprison her in subjectivity, circumscribe her within the limits of her own nature. It is often said that she thinks with her glands" (xxvii). Thus, there is "no peculiarity" in being a man (xxvii), but being a woman implies a derivative, "peculiar" human status. In Beauvoir's schema, the differentiation between sexed identities correlates with the differentiation in the sphere of gender. In her view, women are indeed trapped by biology, but only because the concepts of masculine and feminine have effected this entrapment. Yet Beauvoir ultimately blurs the sex/gender lines, since she does not attempt to establish either 
biology or sexual identity as natural "facts" any less influenced than gender by mythologies and other social forces.

Beauvoir's reading of gender takes shape within her discussion of alternative modes of oppression. She finds the category of the Other useful not only in her conceptualization of relations between the sexes, but in her understanding of the trends of dominant groups to establish patterns of racism, classism, nationalism, and imperialism. She remarks on the tendency of coherent groups to establish their primacy as the One and construct a group of hostile "others" on the outside: ". . . no group ever sets itself up as the One without at once setting up the Other over against itself;" she claims, "If three travelers chance to occupy the same compartment, that is enough to make vaguely hostile 'others' out of all the rest of the passengers on the train" (Beauvoir xxix).

With the construction of these hierarchies, Beauvoir asserts, there is always a corresponding belief system comprised of an elaborate system of justification. She notes, ". . . whether it is a race, a caste, a class, or a sex that is reduced to a position of inferiority, the methods of justification are the same" (xxxv). The dominant class bases its superiority and the inferiority of the Other on a set of ideas of its own creation. Thus, the masculine consists of whatever is valued by patriarchal ruling powers, and the feminine entails whatever is devalorized in phallocracy. Like "the good Negro," to quote her phrase, who is submissive, childlike, and jovial, the "truly feminine" woman plays her role as it has been revealed through dominant ideology: "that is, frivolous, infantile, irresponsible - the submissive woman" (xxxvi).

Although Beauvoir locates the One/Other binary in other categories besides the sexes, she does not proclaim these various oppressions to be identical or comparable. Firstly, the situation of woman as other is an anomalous oppression in that it applies to a group that comprises approximately half of humanity. Usually, Beauvoir comments, ". . . privilege depends upon inequality of numbers-the majority imposes its rule upon the minority or persecutes it" (xxx). Thus, the sweeping nature of women's oppression distinguishes it. Secondly, this oppression depends on the elusive factor of femininity, which is at least in part a construction emanating from patriarchy's rationale for domination. Therefore, Beauvoir remarks that women do not and cannot use "we" in the sense that other oppressed groups do. As a result of the ideological underpinnings of women's secondary 
status, she claims that women "... do not authentically assume a subjective attitude" (xxxi). Beauvoir finds that women, dispersed among men and infused with male ideology, lack the means, or the basis, for organizing. ${ }^{9}$ Thirdly, there was no event that occurred to cause women's otherness; and since it is not a condition arising from a particular social or historical change, it is not a situation that can be duly reversed. She notes, "A condition brought about at a certain time can be abolished at some other time, ... ; but it might seem that a natural condition is beyond the possibility of change" (xxx-xxxi). Therefore, not only is the state of affairs sweeping and non-episodic, but conditions, including the existence of ideological apparatuses, cause the situation of women to appear natural. For Beauvoir, the combination of these factors renders women's oppression rather implausible, yet quite firmly entrenched, and, at times, seemingly insurmountable.

However, while Beauvoir marvels at the phenomenon of women's otherness, she asserts that the Self/Other duality is itself a fixed dichotomy. She states, "The category of the Other is as primordial as consciousness itself" (xxviii); in Beauvoir's words, "Otherness is a fundamental category of human thought" (Beauvoir xxix). She finds dualistic thinking inescapable and asserts that oppositional, conflictual social relations are constituted by the action of consciousness itself. The self, or the subject, must define himself in relation to others as objects. To explain her reliance on a notion of consciousness as dualistic, Beauvoir recounts Claude Lévi-Strauss' view that a passage from a state of Nature to a state of Culture is contingent upon the ability to recognize dualisms in biological relations (xxix). If humanity existed as a Mitsein, which Beauvoir defines as a "fellowship based on solidarity and friendliness" (xxix), she claims this passage would not be possible. The fact that Beauvoir finds a fundamental duality in basic thinking and relations of consciousness makes the conception of consciousness she derives from her readings of Hegel's work an appropriate choice.

Although Beauvoir's description of dualistic thinking draws from Jean-Paul Sartre's divided model of consciousness, she transposes the transcendent self, Being-for-Itself (pour-soi), and the immanent self, Being-in-Itself (en soi), onto Hegel's description of the self-alienated

${ }^{9}$ Beauvoir could add, here, that existence of differences among women frustrates solidarity, as well. 
spirit. $^{10}$ Beauvoir finds Hegel's conception of consciousness useful. She states, "Things become clear, on the contrary, if, following Hegel, we find in consciousness itself a fundamental hostility toward every other consciousness; the subject can be posed only in being opposedhe sets himself up as the essential, as opposed to the other, the inessential, the object" (xxix). Thus, Beauvoir applies Sartrean categories to a Hegelian model of consciousness, which she then transforms into a gendered relation of consciousness. As Jo-Ann Pilardi affirms, "But while Hegel's notion of the subject-object dialectic permitted the subject and object status to move from one person to another, in Beauvoir's analysis, in male-female relations, this dialectical movement freezes. This means that consciousness itself is gendered as a result of patriarchal relations" (29). Hence, Being-in-Itself, humans' material, object-like existence, is connected to the body, wherein Beauvoir identifies women's sexualized, objectified, and subordinated status. This consciousness stands in relation to Being-for-Itself, humans' mobile, conscious existence, which is associated with the mind and with freedom. Therein, Beauvoir locates the privileged subjectivity of men. Within this gendered dynamic, the two genders are in opposition in their struggle for transcendence, yet the Other is continually frustrated by the inability to escape the immanence of this prescribed position.

Beauvoir charges Emmanuel Levinas with composing an alterity which denies the reciprocity of subject and object, a perspective she identifies as a male point of view (xxviii). If her reading of Levinas is accurate, this view is in alignment with Beauvoir's notion of conflictual, oppositional consciousness necessary to the becoming

\footnotetext{
${ }^{10}$ Chanter elucidates the resulting tension created by Beauvoir's attempts to combine a "Sartrian [sic.] model of freedom-which implies the ability of the individual to transcend any situation-and a Hegelian model of the other-which implies an irresolvable conflict between individuals" (50). In this instance, Chanter's focus resides with the consequent shortcomings of Beauvoir's account-especially her failure to "adequately conceive of the interrelation between the role of culture and the question of Women's status as other" due to this "attempt to fuse two incompatible theories" (49). Her analysis of the juxtaposition of Sartre and Hegel in Beauvoir's work provides insightful commentary on the problematic aspects of this maneuver, including the difficulties surrounding Beauvoir's use of the master-slave dialectic.
} 
subject's attainment of subjecthood; she, indeed, maintains that the Self/Other binary is fundamental. However, she maintains that the gendered status of the Self/Other binary is a historically situated relation based on the "assertion of male privilege" (xxviii). The ensuing conflict leads to man's transcendence, but, without reciprocity, it cannot lead to woman's transcendence. Thus, while Beauvoir's construction of consciousness and the self-other relation remain fundamental, the possibility for reciprocity between self and other (at some time in the future) must be left open. The problem of women's frustrated transcendence would have no significance, according to Beauvoir, if we were to accept the determined destiny of physiology, psychology, or economy. The "truly feminine," however, is fashioned by a male point of view (xli), which is itself fashioned to deny women "full membership in the human race" (xli).

It follows, then, that while Beauvoir claims, "Here is to be found the basic trait of woman: she is the Other in a totality of which the components are necessary to one another" (xxxii), she does not consign the gendered relation of consciousness to an inescapable Cartesian duality. The position of woman is one of inferiority, yet it is not an insurmountable subjugation since woman is inferior only insofar as she remains in the context of patriarchy. It is bad faith, according to Beauvoir, to view the plight of oppressed groups as a fixed state. She states that "when an individual (or a group of individuals) is kept in a situation of inferiority, the fact is that he is inferior. But the significance of the verb to be must be rightly understood here: it is in bad faith to give it a static value when it has the dynamic Hegelian sense of "to have become"" (xxxvi). She propounds: "Yes, women on the whole are today inferior to men; that is, their situation affords them fewer possibilities. The question is: should that state of affairs continue?" (xxxvi) Thus, she asserts a dynamic sense of becoming and the instability of a questionable set of conditions.

Throughout, Beauvoir stresses that this inferiority is not accidental or pre-determined but a constitutive outcome of maledominated relations. She points out that "men profit in many more subtle ways from the otherness, the alterity of woman" (xxvii). The male symbolic order depends on the subordinate status of women to remain intact, for if the Other remains suppressed and muted the Self can make culture and history in the image of men, "the most mediocre of [whom]," in her words, "feels himself a demigod as compared with women" (xxxvi). Yet she points out the futility of reversing the binary: 
"If we are to gain understanding, we must get out of these ruts; we must discard the vague notions of superiority, inferiority, equality which have hitherto corrupted every discussion of the subject and start afresh" (xxxix). Here, Beauvoir not only exceeds her "first wave" standing through her rejection of masculinist notions of freedom and power, but surpasses "second wave" agendas in her admonishment of such reversals.

Although Beauvoir's dynamic concept of freedom is presented in existentialist terms, "transcendence"- the liberty of "becoming"-- is conceptually Hegelian: there is no happiness in "being at rest" (xl): "Every subject plays his part as such specifically through exploits or projects that serve as a mode of transcendence; he achieves liberty only through a continual reaching out toward other liberties" (xl). She explains, "There is no justification for present existence other than its expansion into an indefinitely open future. Every time transcendence falls back into immanence, stagnation, there is a degradation of existence into the 'en-soi' - the brutish life of subjection to given conditions-and of liberty into constraint and contingence" (xli). Beauvoir, in fact, asserts that this is "a moral fault if the subject consents to it"; and, if it is inflicted upon the subject, it leads to "frustration and oppression" (xli). It is Beauvoir's belief that "every individual concerned to justify his existence feels that his existence involves an undefined need to transcend himself, to engage in freely chosen projects" (xli). She advances that woman is "a free and autonomous being like all human creatures"; yet a being who "finds herself living in a world where men compel her to assume the status of the Other. They propose to stabilize her as object and to doom her to immanence since her transcendence is overshadowed and forever transcended by another ego (conscience) which is essential and sovereign" (Beauvoir xli).

Beauvoir finds that there may be a temptation for woman to assume the status of an object, but, as long as her status as the Other is questioned and the answers remain lacking, the duality between the sexes will lead to conflict, which may ultimately break the bonds of femininity that constrain woman's becoming. This philosophical positioning suggests the ways in which alterity is later radicalized by second and third generation feminisms and asserted as an oppositional and disruptive force. In fact, the subversive potentiality of this relationship is inherent in its constitution. Ofelia Schutte points out, "The other, the foreigner, the stranger, is that person occupying the 
space of the subaltern in the culturally asymmetrical power relation, but also those elements or dimensions of the self that unsettle or decenter the ego's dominant, self-enclosed, territorialized identity" (54). Additionally, by attributing the factor of subordination to the body within this duality between the sexes, Beauvoir leaves open the possibility for subversion to be connected to the body's radical potential. While this radical potentiality of the body is not a factor of subversion Beauvoir herself commends, or even identifies, it is one which follows from her assertion that what causes the conflict within the sexed duality may provide radical force. It is a mistake, in fact, to diminish or ignore the corporeality of women's alterity and deny the potentiality in subverting subjugation through the "feminine" body, which, through the process of gynesis, has come to represent the unrepresentable, the repressed, and the terrifying.

In her analysis of Biology in Part I of The Second Sex, Beauvoir notes that Aristotle's notion of women as the weaker sex is upheld in Hegel's text, The Philosophy of Nature, wherein he divides the sexes into active and passive components. She states, "Hegel held that the two sexes were of necessity different, the one active and the other passive, and of course the female would be the passive one" (9). She goes on to quote Hegel: "Thus man, in consequence of that differentiation, is the active principle while the woman is the passive principle because she remains undeveloped in her unity" (qtd. in Beauvoir 9). Beauvoir rejects this conclusion, but she still finds that, within the realm of biology, women's roles are crippling. However, it is not the body per se that Beauvoir is rejecting. While the body should not be the starting point for "wild narcissism," a phrase she implements in a 1979 interview with Margaret Simons and Jessica Benjamin, Beauvoir asserts that it should neither be a source of shame (342).

One role Beauvoir views with particular contempt in her biological investigations is women's maternal function. Although she does not accept the difference between the sexes as a natural distinction between activity and passivity, she identifies a division of roles between the sexes in her analysis of mating and the activities that follow procreation. Beauvoir explains: "The male is thus permitted to express himself freely; the energy of the species is well integrated into his own living activity. On the contrary, the individuality of the female is opposed by the interest of the species; it is as if she were possessed by foreign forces-alienated" (25). While she does not make explicit reference to Hegel in her biological investigations, through this 
statement, Beauvoir invokes Hegel's analysis of the pagan ethical world in his Phenomenology, wherein men may pass on to the realization of universality by engaging with the world outside the family and women are said to represent the family and be confined by its particularity. ${ }^{11}$ Throughout this section on Biology, Beauvoir exposes prevailing beliefs about women's bodies for critique and rejection. In the course of her analysis, however, she locates no positive and liberating substance in the corporeal and finds only oppression in maternal functions. In maternity, woman is thought to achieve her ultimate fulfillment, yet Beauvoir contends that there is nothing natural in an obligation to reproduce, nor is having a child a privileged accomplishment. She refuses to affirm the connection between female desire and motherhood. As Linda M.G. Zerilli puts it, "Beauvoir's subversive appropriation of the dominant discourse of motherhood transforms maternity from a self-evident expression of female nature into something strange and profoundly unnatural" (122). Thus, with regard to the body, as it is situated, Beauvoir maintains that women's roles remain limited and limiting.

Beauvoir's analysis of the female/maternal body succeeds in revealing the myths that have dominated male philosophy throughout the ages. For instance, the purportedly passive role of the female in reproduction justifies, for Aristotle, the place of women within patriarchal institutions (Beauvoir 8). Similarly, Beauvoir notes, Hegel affirms this conception of the difference between the sexes (male as active and female as passive) and its corresponding logic in reproductive functions (9). Beauvoir concludes of mammalian females within the realm of biology: "At times when she is free from maternal servitude she can now and then equal the male. .." (23). Unlike women's place in childrearing, the man's role remains separate and distinct. She states, “. . . he keeps himself apart and maintains his individuality within himself" (23). Beauvoir continues, "In this respect Hegel is right in seeing the subjective element in the male, while the female remains wrapped up in the species" (23). Genevieve Lloyd claims that it is Beauvoir's commentary on female biology that elucidates the conflict between being a free subject, reaching for

${ }^{11}$ The limited role of women is also discussed by Hegel in The Philosophy of Right, where, as in the Phenomenology, Hegel invokes the figure of Antigone to elucidate this. However, in The Philosophy of Right, Hegel's focus is on women's role in the modern world, rather than in the pagan world of the Phenomenology. 
transcendence, and being a body which drags this subject back to a "natural" existence (306). Lloyd asserts, "It is as if the female body [in Beauvoir's account] is an intrinsic obstacle to transcendence, making woman a "prey of the species"' (306).

Even as Beauvoir "defamiliarizes the familiar" and "denaturalizes the natural" (Zerilli 122), she explores the possibility that menopause frees women from "the iron grasp of the species" (Beauvoir 31). She expounds: "Woman is now delivered from the servitude imposed by her female nature, but she is not to be likened to a eunuch, for her vitality is unimpaired. And what is more, she is no longer the prey of overwhelming forces; she is herself, she and her body are one" (31). Beauvoir questions the status of post-menopausal women as a possible "third sex" (31); she proposes that women in this stage of life are "no longer females" (31). She remarks, "Often, indeed, this release from female physiology is expressed in a health, a balance, a vigor that they lacked before" (31). Thus, Beauvoir's seeming rejection of female corporeality resides largely in her critique of maternal roles.

These roles are socially and ideologically situated, however. And though Beauvoir does not suggest that women attain transcendence by identifying with their bodies, she is certainly not advocating a universal rejection of the body. She states, ". . . the body is not a thing, it is a situation . . . ; it is the instrument of our grasp upon the world, a limiting factor for our projects" (Beauvoir 34). Beauvoir insists upon woman's "power to choose between the assertion of her transcendence and her alienation as object" (50). Woman exists in a world of ideas and values that hamper her transcendence, yet Beauvoir believes that she has the capacity for freedom. Thus, Beauvoir's account of the maternal body does not suggest that being physiologically female presents an insurmountable obstacle to the existentialist ideal of transcendence. Rather, it results in a useful theory of bodily alienation. $^{12}$

${ }^{12}$ As Kristana Arp suggests, "One of the primary ways, if not the primary way that women are conditioned to accept their oppression is through bodily alienation. And the alienation of women in their bodies and from their bodies has been effected through male ideology. For these reasons, Beauvoir's concept of bodily alienation is a major contribution to feminist thought" (174). 
Much later in the text, following her reflections on the alternative lesbian's life, in which she locates potential in the independence of the lesbian, who is defined not by her "erotic life" but by what Beauvoir calls the "whole group of responsibilities [lesbians] are forced to assume because they dispense with men" (421), she embarks on a more thorough consideration of forces within the realms of marriage and motherhood (Part V, "Situation"). Though she concedes that marriage is becoming a more egalitarian union which is entered into by independent, consenting persons, whose obligations are reciprocal, and that women are no longer limited to the reproductive function, she maintains that marriage still, to some degree, perpetuates the past (425). It is appropriate that Beauvoir's extended engagement with Hegelian tropes takes place within this realm of the symbolic, conflating, as it does, women's potential reproductive capacity-or her "natural" and self-fulfilling roles as wife and mother-with social function and ontological status. Hence, it is here, in "The Married Woman," that Beauvoir most fully engages with two key Hegelian moments that further express the self-other divide: the meeting of human and divine law in the ethical realm and the master-slave dialectic.

\section{Beauvoir's Otherness in Hegel's Ethical Realm}

The first Hegelian reference Beauvoir incorporates in her analysis of marriage is the dialectic of particular and universal, or the opposition between human and divine law, in the ethical realm. She refers to "the very doctrine enunciated by Hegel when he maintains that woman's relations as mother and wife are basically general and not individual" (435) and notes that only man transcends "toward the universal as worker and citizen" (435). Beauvoir also comments on the biological, or ontological, basis on which Hegel's justification rests. In Hegel's analysis of the family, woman, because of her nature, both represents and is confined to the dark, lower world of shadows-the realm of the family and divine law. Woman is not alienated from nature since she does not experience a confrontation, or contradiction, between herself and first nature, or particularity. She is denied her dialectical development, since this requires the overcoming of natural existence through the conscious risk of death for recognition in the community. Woman is responsible to the family and, thus, unlike men, cannot proceed beyond its realm. Therefore, woman always remains ethical substance without self-consciousness. She only achieves knowledge as intuition of divine law and never achieves the abstract individuality of a citizen; she remains confined to her particularity. Hegel explains: "But 
because it is only as a citizen that he is actual and substantial, the individual, so far as he is not a citizen but belongs to the Family, is only an unreal impotent shadow" (270). Since woman is confined to this world of shadows, or the lower world of the family, and remains trapped within the realm of first nature, or particularity, her selfdevelopment, or transcendence, is halted.

The progression of human consciousness from the particularity of the family to the realization of universality is limited to the male sex. Hegel states:

The brother is the member of the Family in whom its Spirit becomes an individuality which turns towards another sphere, and passes over into the consciousness of universality. The brother leaves this immediate, elemental, and therefore, strictly speaking, negative ethical life of the Family, in order to acquire and produce the ethical life that is conscious of itself and actual. He passes from the divine law, within whose sphere he lived, over to human law. But the sister becomes, or the wife remains, the head of the household and the guardian of divine law. (275)

As in the Phenomenology, Beauvoir's analysis recognizes the husband's "position of moral and social superiority" (Beauvoir 463). She elaborates: "He has the advantage of superior culture or, at any rate, professional training; since adolescence he has taken an interest in world affairs - they are his affairs - he knows something of law, he keeps up with politics, he belongs to a party, to a union, to social organizations; as worker and citizen his thinking is related to action" (463). For Beauvoir, social conditions are the cause of this injustice, or this "basic inequality" of the sexes. In her words, "But the basic inequality still lies in the fact that the husband finds concrete selfrealization in work and action ..."(480). She proclaims, "[women's] miscellaneous information does not constitute culture" (463); but it is "intellectual technique" women lack - not intellect (463). Beauvoir continues: "That is why their husbands, even though of comparatively mediocre ability, will easily dominate them and prove themselves to be in the right even when in the wrong" (463). As is the case with Hegel's rationale, Beauvoir claims, "In masculine hands logic is often a form of violence, a sly kind of tyranny. .." (463). Thus, she exposes the justification of patriarchy in her discussion of Hegel's ethical realm, even though she does not overtly admonish Hegel's masculine logic. 
This Hegelian reference plays a provocative role within Beauvoir's own analysis. It reveals that freedom, as it has been manifested in patriarchal society, is male and that this is justified in Philosophy and in various other masterdiscourses by biological assumptions. By locating an ideological justification of patriarchy in Hegel's Phenomenology, Beauvoir may be locating both the forces of oppression and the forces of subversion. In drawing out tensions that exist in that text, Beauvoir is defying Hegel's narrative. Beauvoir's denial of subjectivity within Hegelian concepts and narratives challenges the symbolic order from within. Like Marx, she utilizes Hegel, but with new purpose. ${ }^{13}$ And, like many feminist writers, Beauvoir views Hegel's text as a point of contestation.

\section{Beauvoir's Master-Slave Dialectic}

Beauvoir's second major reference to the Phenomenology is the master-slave dialectic, the Hegelian paradigm most frequently revisited in Beauvoir studies. It is first set forth as a general sexed dynamic in Part II. Therein, Beauvoir asserts, "Certain passages in the argument employed by Hegel in defining the master to slave apply much better to the relation of man to woman" (64). But it is within the realm of the marriage relation that Beauvoir suggests its "most concrete application" (481). She claims, "Very often it is not enough for the husband to be approved of and admired, for him to be counselor and guide; he issues commands, he plays lord and master" $(465) .{ }^{14} \mathrm{By}$

${ }^{13}$ Further, like Marx, it is clear from the connections she draws between supply and demand and relations between the sexes that Beauvoir finds economic transformation essential to any substantive and lasting reformulation of such relations, even if it is only a part of this reformulation. For woman's greater involvement in "species life" frustrates her transcendence, but it is the prevailing modes of socioeconomic organization that limit her "projects" and "exploits" to this realm of domestic and maternal activity, or cut woman off from the potential lived meanings of her subjectivity. In the last paragraph of this section, Beauvoir directly states that women's liberation, indeed, "must be collective, and it requires first of all that economic evolution of women's condition be accomplished" (627). For Beauvoir, both economic change and the concomitant struggle to "disrupt cultural assumptions about woman as the passive bearer of species teleology" (Zerilli 119) are collective enterprises.

${ }^{14}$ Given the direct nature of these statements, it is curious that Eva Lundgren-Gothlin claims that Beauvoir "does not locate man as master 
referencing the master-slave dialectic, Beauvoir contends that the subjugation of women by men gives rise to the condition of mastery and servitude within marriage. However, while the Hegelian master-slave dialectic does apply in this general, yet limited, sense, there are vital aspects of this dynamic which do not apply. This may initially appear to be simply a partial appropriation of Hegel, but these absences give her Hegelian reference more significance than may be readily apparent. ${ }^{15}$

One element of the master-slave dialectic instrumental in social theory and absent in Beauvoir's analysis is the reversal which takes place. In Hegel's analysis, the master's desire to be recognized is frustrated by the act of subjection, and this precipitates a reversal within the master-slave relationship. The master cannot attain pure selfconsciousness because the recognition necessary for the movement from consciousness to self-consciousness is only achieved by the exercise of force. Any recognition gained from the slave, whose fear of death causes him to yield to the master's will, is a forced recognition. The slave recognizes the master only because he is obliged to do so; therefore, the recognition of servant is the reflection of the master's will back to himself through the will of the slave, which is really nothing more than the will of the master. The master, recognizing himself, does not gain recognition at all. The slave, however, experiences the dread of human existence- the threat of Nothingness, or the negation of being - and understands human reality better than the master does. Hegel states, "But just as lordship showed that its essential nature is the reverse of what it wants to be, so too servitude in its consummation will really turn into the opposite of what it immediately is; as a

and woman as slave in this [Hegelian master-slave] dialectic" (72). I will return to this shortly.

${ }^{15}$ While Chanter claims that Beauvoir's "existentialist bias. . . results in a failure to take the dynamic aspects of Hegel's dialectical thinking seriously" (66); questions how Hegel's master-slave relation, in Beauvoir's mind, applies better to the relation between man and woman (Chanter 67); and ascribes fundamental problems to Beauvoir's assimilation of Hegel and Sartre; I will identify the richness in Beauvoir's text, departing from Chanter's assertion that Beauvoir's "existentialist standpoint" prevents Beauvoir from taking full account of Hegel's master-slave dialectic. Chanter's notion that there may be an "internal contradiction" (72) yields an insightful reading, but does not explore the potential in Beauvoir's text I elucidate herein. 
consciousness forced back into itself, it will withdraw into itself and be transformed into a truly independent consciousness" (Hegel 117). So it is finally the slave who undergoes a significant movement of Spirit and, in fact, experiences the first moment of freedom. In Beauvoir's analysis, woman as subordinate or slave does not experience even this momentary transcendence.

A second aspect of the Hegelian master-slave dialectic which does not exist in Beauvoir's discussion of marriage is the crucial importance of labor. It is through labor that the slave is able to achieve successful externalization of self in the Phenomenology. The slave, who receives no recognition, exercises his own will on the external world and overcomes the otherness of the physical material world through labor and the development of the skills it entails. Thus, in laboring for another without recognition of himself as a self, the slave, the bearer of physical labor, achieves independence through the acquisition of knowledge and the projection of himself into the future through productive labor. The slave makes the world other than it was and, hence, changes himself, whereas the master only changes through the slave. This externalization of self allows the slave to become other through work. The process of labor and its projection into the social world yields positive results for the slave in that he realizes selfhood through work and the permanence of its results.

The wife in Beauvoir's The Second Sex is condemned to the torturous labor of housework and produces no durable products, so she never experiences these positive results. Beauvoir claims that the wife's labor is analogous to the torture of Sisyphus. Camus describes this torture: "The gods had condemned Sisyphus to ceaselessly rolling a rock to the top of a mountain, whence the stone would fall back of its own weight. They had thought with some reason that there is no more dreadful punishment than futile and hopeless labor" (88). Similarly, the wife "makes nothing," and "simply perpetuates the present," according to Beauvoir (451). In the endless repetition of housework, the wife engages in this "futile and hopeless" attempt to halt decay. Beauvoir calls this negative activity a "denial of life" (451). She elaborates: "The woman's work within the home gives her no autonomy; it is not directly useful to society, it does not open out on the future, it produces nothing. It takes on meaning and dignity only as it is linked with existent beings who reach out beyond themselves, transcend themselves, toward society in production and action" (456). The husband, on the other hand, "is first a citizen, a producer, secondly a husband" (456). 
Thus, the master-slave dialectic in the situation of marriage in The Second Sex is quite divergent from that of the Phenomenology. Beauvoir's reference is limited to the fact of subordination and the general frustration of recognition within the marriage relationship. There is no reversal between husband and wife, no achievement of selfconsciousness through labor, and, although desired, no transcendence for wife. Eva Lundgren-Gothlin claims that the seeming limitations of Beauvoir's reference can be explained by viewing woman as outside the process of recognition entirely. She states:

I am therefore claiming, in contrast to other scholars, that while Beauvoir uses the Hegelian master-slave dialectic to explain the origins of oppression, she does not locate man as master and woman as slave in this dialectic. Instead, woman is seen as not participating in the process of recognition, a fact that explains the unique nature of her oppression. Although the man is the master, the essential consciousness in relation to woman, the woman is not a slave in relation to him. This makes their relationship more absolute, and non-dialectical, and it explains why woman is the absolute Other.

(Lundgren-Gothlin 72)

In her interpretation of Beauvoir's use of the master-slave dialectic, both master and slave are male, as in Hegel's rendering, while woman remains absolute other. Here, Lundgren-Gothlin emphasizes that this relation is non-dialectical, as the master and slave do not authentically engage in the process of recognition; further, in a footnote, she exposes critics who believe that "Beauvoir did not take the time to learn her Hegel thoroughly" (277). These are, indeed, useful observations. However, in contrast to Lundgren-Gothlin, I am not willing to part with the notion that Beauvoir intended the master-slave relation to be a sexed dynamic or that Beauvoir consciously used it only up to a certain point, culling from it what was useful to her. My reading of this partial application of the master-slave dialectic draws significance from the idea that, in Beauvoir's formulation, the fact of subordination may not be necessary for transcendence. Indeed, there is no reversal in Beauvoir's dynamic because master and slave do not engage in authentic recognition. Further, there is no successful externalization of self for the wifetherefore, no validation of "women's work," so to speak, insofar as it is tedious, unpaid, and functions only to serve others. Thus, by applying Hegel's master-slave dialectic in such a limited fashion, Beauvoir emphasizes that there are no positive results from subjugation for the wife, and certainly not through the labor of a wife. 
In her earlier critique of historical materialism, Beauvoir focuses on how the interplay of women's economic and social oppression is largely perpetuated, in her estimation, by domestic slavery and women's lack of participation in production. However, she stresses that economic factors do not suffice to explain or remedy the situation of women. Beauvoir notes, "If the human consciousness had not included the original category of the Other and an original aspiration to dominate the Other, the invention of the bronze tool could not have caused the oppression of women" (58). Thus, although Beauvoir asserts that women's emancipation is, in part, tied to her attainment of equal rights and her involvement in large-scale production, or projects of her own choosing, and while a limited engagement in domestic labor may be necessary, Beauvoir's treatment of labor, in the master-slave relation and beyond, serves to reassert her claim that women's situation is complex and may not be rectified through labor, and especially through domestic labor. By stating that it is the "imperialism of the human consciousness. . . seeking always to exercise its sovereignty in objective fashion" (58), which limits women's transcendence, Beauvoir once again posits a Hegelian model of consciousness.

Ultimately, by implementing resources from Hegel's Phenomenology, Beauvoir illustrates the fact that women's liberation, or transcendence, cannot be achieved within the Hegelian narrative, which is still, to a large extent, the narrative of our patriarchal world. It seems Beauvoir utilizes the Hegelian system to expose this narrative of patriarchal ideology which women must collectively resist in order to achieve the conditions that will allow for the affirmation of women's freedom, or transcendence. ${ }^{16}$ Perhaps she approaches Hegel's system with a view towards illuminating the complex and far-reaching effects of patriarchal power and its ideological tentacles, but also towards locating the means by which to change women's lives. But the question remains: How can this be achieved within this conflictual model of consciousness? Without rescinding her previous claim that consciousness is essentially combative, Beauvoir suggests that women's

${ }^{16}$ Here, Elaine P. Miller might agree. In her reading, she claims that Beauvoir's treatment of Hegel (in The Second Sex and The Ethics of Ambiguity taken together) and, in particular, Beauvoir's "resistance to the Hegelian sublation of particularity into the universality and neutrality of the ethical" in The Ethics of Ambiguity, foregrounds Irigaray's concern for the development of "specifically feminine values and even a feminine subjectivity" (122). 
emancipation is a future possibility. And, despite the many forces denying women's transcendence, she alludes to this hope when she suggests, "The free woman is just being born" (Beauvoir 715). Thus, Beauvoir leaves the question of the self-other schematic open to interpretive possibilities, even as she maintains a position of intransigence regarding its basic constitution.

\section{Conclusion}

Beauvoir recognizes that it is in the interest of men to retain their position within patriarchal societies and develop systems of thought, among them gender, and perpetuate tradition in the form of conventional values and standard roles, which, in turn, help to perpetuate existing relations of power. In the course of elucidating the concept of the Other, Beauvoir confronts these constructs and unmasks them. She separates the dynamics of gender, in a sense, from the biological and the metaphysical by exposing the belief systems that support dominant ideas about women as Other. Her efforts to establish the indeterminacy of gender and its status as an ideological construction-the effect of socialization and not the necessary outcome of some pregiven interior essence or the fabrication of the woman's will, or choice-raise questions about the ultimate injustice the Self/Other binary reinforces and provide important breakthroughs for later feminist projects. Building upon Beauvoir's observations, Judith Butler, for instance, calls into question the stability and coherence of the very category of woman, not only as an identity construction, but as a foundation for feminist politics, since this category takes shape within the context of a matrix that oppositionally and hierarchically defines gender through the compulsory practices of gender identity and invariably supports relations of psychic and political subordination. ${ }^{17}$ The resources of Beauvoir's concept of otherness have indeed proven invaluable.

Additionally, the self-other problematic that Beauvoir centralizes leaves space for the Other to be developed into a radical position of alterity and femininity, as a construct, to be turned against the systems that create and perpetuate it as an instrument of oppression. "French feminists," for example, have attempted to radicalize alterity rather than reject the "otherness" of women as a plight to be "overcome."

${ }^{17}$ In Gender Trouble.

${ }^{18}$ The development of concepts, such as féminité and l'écriture féminine exemplify this approach to otherness. Note, for instance, 
locate a site for resistance in this otherness and reconceive of alterity as a radical force or positionality with the potential to destabilize hegemonic systems. Transformations of otherness as radical do not succeed as reversals of the Self/Other binary, however. If they retain hierarchical relations between the sexes, they are incomplete alterations. In transforming Beauvoir's account of sexist relations, an attempt must be made to reconceptualize, or even reconstitute, relations between the sexes, or, rather, between any subjects in hierarchical relation. But how do we break free from dominating forms of power? Is the necessary form of power one that subjugates? $?^{20}$ These are questions contemporary feminists continue to address.

While some feminists recognize the vitality of the concept of woman as the Other and attempt to posit this force against a divided model of human relations, it remains important for others to reconsider the necessity for antagonism inherent in Beauvoir's formulation of consciousness, as Irigaray attempts in her later development of the concept of the universal as two. ${ }^{21}$ The importance of overcoming this problem is alluded to by Kelly Oliver when she asserts, "Until we can conceive of a true relation between subject and other, we cannot conceive of ethics" (1). Yet Beauvoir herself does not question the dualistic, oppositional thinking that generates such categories. Throughout The Second Sex, she remains committed to the antagonistic model of consciousness that she has derived from her reading of Hegel.

Hélène Cixous's "The Laugh of the Medusa," which is considered a manifesto for l'écriture féminine.

${ }^{19}$ For example, "This Sex Which Is Not One," where Irigaray asserts feminine autoeroticism against masculine economies of sexuality and general phallocentric oppression.

${ }^{20}$ See Butler's The Psychic Life of Power.

${ }^{21}$ In I Love To You, Irigaray attempts to replace the logic of One with the logic of two, thereby disrupting major systems that order knowledges and discourses, such as the phallic economy of the Hegelian dialectic. This entails the development of a sexuate economy, for Irigaray claims that sexual difference must be accounted for in any constitutive ontology of renewal and revolution. The incommensurability of sexed exchange disrupts the "universal" and offers a model of negotiation, reciprocity, recognition, and mediation between subjects. 
Beauvoir's employment of Hegelian paradigms and narratives is tempered, however, by the fact that she finds that Hegel, in some instances, does not assert the truth, but, rather, makes many of the very claims she rejects and demystifies in the course of her exposition of the Other. Not only does she derive what she deems a fitting model of consciousness and the master-slave power dynamic from Hegel, but she utilizes Hegel to reveal the inner workings of patriarchal systems as she exposes the justification of subordination in the master-slave relation and the rationale for patriarchy in Hegel's ethical realm. Throughout her engagement with Hegel, as well as other masculinist philosophers, Beauvoir locates useful descriptions for her own critique. That Freud and others are describing the mental representation of a social reality and not reality itself did not escape Beauvoir. Yet she maintains an allegiance to certain ideas that limit her theory of alterity in irreparable ways-above all, to a construction of otherness that maintains a focus on antagonism rather than mediation and reciprocity. Yet the very formulation of the concept of the social other and its status as gendered is itself radical, given its historical location.

In conclusion, the relationship between feminists and their male predecessors is indeed complex. The philosophical texts of our male predecessors have represented and yielded dominant modes of thought that are ingrained in both the profound and the political, our philosophical underpinnings and our everyday experiences. Rather than simply appropriate or combat phallocentric thought, third generation feminists position themselves in a dialogue with their philosophical predecessors. Taking clues from Beauvoir, thinkers such as Irigaray and Kristeva simultaneously interrogate philosophical tradition and employ various resources they have located and transformed. There is a struggle: for the reclamation of a corpus of work that is rich with philosophical insights and for the rejection of the underlying patriarchal themes of these texts that exist in the logic of our culture, economy, and everyday lives. This approach yields more than a methodology for third wave feminist projects, but it may hold meaning beyond these enterprises. Beauvoir begins to unfold this story, and later generations further radicalize it.

By keeping the relationship of self and other in motion, conceptually, we may find that rather than a cruel struggle of oppressive and hostile forces in a linear process of becoming, as in Hegel's dialectic of Aufhebung, the self-other relation, set free from strict sex and gender categories and a conflictual model of consciousness, can be 
reconceived as an affirmative interplay of forces, or a dialectical oscillation. The richness of corporeal paradigms developed by later thinkers, such as Irigaray, allude to the ways we can begin to rethink these relations. ${ }^{22}$ Perhaps we may even glimpse the potential for rethinking these relations in the philosophical space between the corpus of feminist writings and the masterdiscourses they engage.

The University of Alabama Jennifer Purvis

\section{Works Cited}

Arp, Kristana. "Beauvoir's Concept of Bodily Alienation." Simons, Feminist 161-77.

Beauvoir, Simone de. The Second Sex. Trans. H. M. Parshley. New York: Vintage, 1989.

Bergoffen, Debra B. The Philosophy of Simone de Beauvoir:

Gendered Phenomenologies, Erotic Generosities. Albany: State U of New York P, 1997.

Butler, Judith. Gender Trouble: Feminism and the Subversion of Identity. New York: Routledge, 1990.

---. The Psychic Life of Power: Theories in Subjection. Stanford: Stanford UP, 1997.

Camus, Albert. "The Myth of Sisyphus." "The Myth of Sisyphus" and Other Essays. Trans. Justin O'Brien. New York: Vintage, 1955. 1-92.

Chanter, Tina. "The Legacy of Simone de Beauvoir." Ethics of Eros: Irigaray's Rewriting of the Philosophers. New York: Routledge, 1995. 47-79.

Cixous, Hélène. "The Laugh of the Medusa." New French Feminisms. Ed. Elaine Marks and Isabelle de Courtivron. New York: Schocken, 1981. 245-64.

Fullbrook, Edward and Kate Fullbrook. Simone de Beauvoir: A

Critical Introduction. Cambridge: Polity, 1998.

---. Simone de Beauvoir and Jean-Paul Sartre: The Remaking of a Twentieth-Century Legend. New York: Basic, 1994.

Hegel, G. W. F. Phenomenology of Spirit. Trans. A. V. Miller. Oxford: Oxford UP, 1977.

Heinämaa, Sara. "Simone de Beauvoir's Phenomenology of Sexual Difference." Hypatia 14.4 (1999): 114-32.

Irigaray, Luce. "The Eternal Irony of the Community." Speculum of the

${ }^{22}$ Irigaray's placental economy and procreative couple exemplify this type of corporeal paradigm (je). 
Other Woman. Trans. Gillian C. Gill. Ithaca: Cornell UP, 1985. 214-26.

---. I Love To You: Sketch of a Possible Felicity in History. Trans.

Alison Martin. New York: Routledge, 1996.

---. je, tu, nous: Toward a Culture of Difference. Trans. Alison Martin. New York: Routledge, 1993.

---. Sexes and Genealogies. Trans. Gillian C. Gill. New York: Columbia UP, 1993.

---. "This Sex Which Is Not One." This Sex Which Is Not One. Trans. Catherine Porter and Carolyn Burke. Ithaca: Cornell UP, 1985. 23-33.

Kristeva, Julia. Revolution in Poetic Language. Trans. Margaret Waller. New York: Columbia UP, 1984.

---. "Women's Time." Trans. Alice Jardine and Harry Blake. Signs: Journal of Women in Culture and Society 7.1 (1981): 13-35.

Kruks, Sonia. "Simone de Beauvoir: Teaching Sartre About Freedom." Simons, Feminist 79-95.

Le Doeuff, Michèle. Hipparchia's Choice: An Essay Concerning Women, Philosophy, Etc. Trans. Trista Selous. Oxford: Blackwell, 1989.

---. "Simone de Beauvoir: Falling into (Ambiguous) Line." Trans. Margaret Simons. Simons, Feminist 59-65.

Lloyd, Genevieve. "Masters, Slaves, and Others." Radical Philosophy Reader. Ed. Roy Edgley and Richard Osborne. London: Verso, 1985. 291-309.

Lundgren-Gothlin, Eva. Sex and Existence: Simone de Beauvoir's The Second Sex. Trans. Linda Schneck. Hanover: Wesleyan UP, 1996.

Miller, Elaine P. “The 'Paradoxical Displacement': Beauvoir and Irigaray on Hegel's Antigone." The Journal of Speculative Philosophy 14 (2000): 121-37.

Mills, Patricia Jagentowicz. Introduction. Feminist Interpretations of G.W.F. Hegel. Ed. Patricia Jagentowicz Mills. Re-Reading the Canon. University Park: Pennsylvania State UP, 1996. 1-24.

Oliver, Kelly. "Introduction: Julia Kristeva's Outlaw Ethics." Ethics, Politics, and Difference in Julia Kristeva's Writing. New York: Routledge, 1993. 1-22.

Pilardi, Jo-Ann. "Self and Other in The Second Sex." Simone de Beauvoir Writing the Self: Philosophy Becomes Autobiography. Contributions in Philosophy 60. Westport: Greenwood P, 1999. 25-38. 
Schutte, Ofelia. "Cultural Alterity: Cross-Cultural Communication and Feminist Theory in North-South Contexts." Hypatia 13.2 (1998): 53-72.

Simons, Margaret A. "Beauvoir and Sartre: The Philosophical Relationship." Yale French Studies 72 (1986): 165-180.

---. "Beauvoir's Early Philosophy: The 1927 Diary (1998)." Beauvoir and The Second Sex: Feminism, Race, and the Origins of Existentialism. Lanham: Rowman, 1999. 185-243.

---. "Beauvoir's Philosophical Independence in a Dialogue with Sartre." The Work of Simone de Beauvoir. Spec. Issue of The Journal of Speculative Philosophy 14 (2000): 87-103.

---, ed. Feminist Interpretations of Simone de Beauvoir. University Park: Pennsylvania State UP, 1995.

Simons, Margaret A. and Jessica Benjamin. "Simone de Beauvoir: An Interview." Feminist Studies 5 (1979): 330-45.

Vintges, Karen. Philosophy as Passion: The Thinking of Simone de Beauvoir. Trans. Anne Lavelle. Bloomington: Indiana UP, 1996.

Von Flotow, Luise. "Translation Effects: How Beauvoir Talks Sex in English." Contingent Loves: Simone de Beauvoir and Sexuality. Ed. Melanie C. Hawthorne. Charlottesville: UP of Virginia, 2000. 13-33.

Zakin, Emily. "Differences in Equality: Beauvoir's Understanding of the Universal." The Journal of Speculative Philosophy 14 (2000): 104-20.

Zerilli, Linda M.G. "A Process without a Subject: Simone de Beauvoir and Julia Kristeva on Maternity." Hypatia 18.1. (1992): $111-35$. 